V.Shpachuk, Dr. Sc. (Public Admin.), Assoc. Prof., orcid.org/0000-0003-1322-3257,

O. Yevmieshkina, Dr. Sc. (Public Admin.), Assoc. Prof., orcid.org/0000-0001-6006-7563,

V. Kravchenko, Cand. Sc. (Public Admin.), Assoc. Prof., orcid.org/0000-0001-9396-4885
V.I. Vernadsky Taurida National University, Kyiv, Ukraine, e-mail: mfkoorg@gmail.com

\title{
THE IMPACT OF MINE WATERS ON THE CONDITION OF THE WATER MANAGEMENT COMPLEX OF UKRAINE: TASKS OF WATER MANAGEMENT
}

Purpose. To formulate the tasks of the water management of Ukraine in the conditions of the existing danger of violation of the basin balance of the development of water management in Ukraine by the mine waters.

Methodology. The methodological basis of the study is the simulation of the impact of mine waters on the basin balance of water management, analysis, synthesis and comparison of the obtained results.

Findings. To achieve this goal, the authors considered: 1) the reasons due to which the mine waters are regarded to be a polluting object, and, accordingly, dangerous for the water management complex of Ukraine; 2) the state and possibilities of physical, chemical and biological technologies of mine water treatment; 3 ) the general functions of water management. The obtained results allowed formulating specific tasks of water management to prevent the mine waters from violating the basin balance of the development of water management in Ukraine.

Originality. The authors identified the tasks of water management of Ukraine based on the results of the analysis of the characteristics of pollution by the mine waters of groundwater and natural surface waters, as well as the imperfections of the existing mine water treatment technologies.

Practical value. The study reveals the role of water management in the environmental safety of the state. The results can be useful in the work of state authorities, owners of mining enterprises, scientific and public organizations of environmental orientation on the issue of the treatment of mine waters as a part of the global water system safety. The obtained results can be used in the structure of educational programs for training specialists in the specialty "Public management and administration", as well as expand the qualification of water management at all levels: from state regulation to management in the regions. The formulated tasks of water management will ensure the effective management of mine waters and basin balance of the development of water management in Ukraine.

Keywords: mine waters, water management complex, water management, environmental safety, treatment technologies

Introduction. In the mining industries, the conflict between economic progress and environmental quality is the most pronounced. On the one hand, the need for energy resources and energy safety of the state stimulate the exploration and production of minerals and, accordingly, the development of mining enterprises. However, on the other hand, engineering processes, physical and chemical waste of mines are an unbearable anthropogenic load on ecosystems, with which they are not able to cope on their own.

In the second half of the $20^{\text {th }}$ century, land reclamation technologies reached a new level of perfection, which made it possible to reduce the negative impact of the mining industry on the quality of the environment. The integration of engineering, chemistry and microbiology has opened up new possibilities for mine reclamation. However, there are still enough problems. For example, the authors of the book "Mine Water: Hydrology, Pollution, Remediation" showed that even modern technologies for the prevention and treatment of mine waters could not completely solve the problem of pollution of groundwater and surface water [1]. In many cases, pollution of underground and natural surface waters with mine water lasts longer than the term of operation of the mine. This fact not only significantly increases the true cost of long-term responsibilities for water treatment, but it also makes the management of the water supply complex responsible for the control of mine melioration. This fact expands and clarifies the complex of primary tasks facing the water management of Ukraine.

In the proposed article, the authors will formulate the tasks of water management of Ukraine under the conditions of the existing danger of a violation of the basin balance of the development of the water economy of Ukraine by mine waters. The authors will consider the reasons why mine waters are considered dangerous for the water complex of Ukraine; existing technologies of mine water treatment, as well as water

(C) Shpachuk V., Yevmieshkina O., Kravchenko V., 2019 management tasks following from the peculiarities of the influence of mine waters on the state of the water supply complex of Ukraine.

Results. Water management is a branch of the economy of Ukraine. The main task of the water management is to provide the population with water, as well as other branches of the economy. In the current Order of the Cabinet of Ministers of Ukraine "On Approval of the Concept of the National Target Program for the Development of Water Management for the Period until 2020" the following figures of water management of Ukraine are presented: " 15.7 billion cubic meters of water was taken for their needs from water bodies in 2008. Annually, $8.3-8.5$ billion cubic meters of polluted industrial and municipal effluents are discharged into the water bodies of the country, 0.6 billion cubic meters of which are untreated and 2.1 billion cubic meters are treated insufficiently. The level of water capacity of industries and housing and communal services is 2.5-3 times higher than the world level" [2].

In accordance with the Decree of the Cabinet of Ministers of Ukraine "On Approval of the Regulations on the State Register of Potentially Hazardous Objects", the Registry database was created, which contained the information about potentially dangerous objects, including hydrotechnical facilities and coal mines [3]. This testifies to the relevance of research on the problem of mine water and the many-sided nature of the tasks of dealing with them, and eliminating the consequences of the influence of these waters on the environment.

In the total amount of polluted runoff, mine waters occupy a special place. Mine water is the outflow of acidic water from metallurgical or mining mines. This outflow can occur naturally, as a part of the rock weathering process. However, in most cases, the outflow of acidic water is caused by mining activity, which is associated with the extraction of large amounts of rocks to the surface and pumping water from the mines. In essence, mine water, for the most part, is a pollutant, or acid mine drainage (AMD). A special feature of mine 
waters is the presence of dissolved metals in them, such as Fe, $\mathrm{Mn}, \mathrm{Cu}, \mathrm{Ni}$ and $\mathrm{Zn}$ in concentrations that are much higher than the concentration of these metals in natural water bodies.

Mining activity changes the hydrogeology of the region. First of all, the changes affect:

1. Balance and chemical composition of groundwater. Highly mineralized acidic mine waters are formed in which colonies of bacteria and archaea multiply rapidly. Under natural conditions, these microbes (extremophiles) due to limited access of water and oxygen are found in limited quantities. However, mining activity contributes to their intensive reproduction, as a result of which increased acidity of water is formed.

2. There is a natural, but mainly artificial outflow of mine water, which leads to pollution of surface and ground waters. Especially dangerous is the pollution of groundwater, which becomes unsuitable for domestic water supply, and sometimes for technical water supply. Acid drainage has been developing for decades and even centuries. Therefore, mine water treatment is considered a serious long-term environmental problem.

3. Mine water pollution of the aquifers of fresh groundwater, which is used by the local population for domestic purposes. Groundwater treatment technologies surpass considerably on cost of natural surface water purification technology. In addition, monitoring of pollution of aquifers often occurs out of time, which leads to the poisoning of people with drinking water. Contaminated aquifers affect the health of people in coal mining regions and, respectively, their quality of life.

The chemical composition of mine water is complex and constantly changing. The main features are:

1. When the mine water $\mathrm{pH}$ is above 3 , or after the contact of the mine water with fresh water or neutralizing minerals, the previously soluble iron (III) ions precipitate as iron (III) hydroxide, oxides and iron oxyhydroxides.

2 . As a result of this process, additional hydrogen ions are also formed, which can further reduce the $\mathrm{pH}$ of the water. All these sediments lead to the death of plant and animal life.

To combat mine waters, modern treatment technologies are actively used:

1. Physical treatment (for example, simple physical cleaning with pure water circulation).

2. Chemical treatment (for example, lime treatment).

3. Biological treatment methods (for example, the use of aerobic wetlands, or compost bioreactors).

4. Integrated treatment technologies including various combinations of physical, chemical, and biological cleaning methods.

In order to allow mine water to be discharged into natural water bodies, it must be treated to a $\mathrm{pH}$ of $6-9$.

Let us consider the examples and the state of physical, chemical, biological and integrated methods of mine water treatment.

The most common method of mine water treating is the lime treatment. For example, in the article "Water purification from sulphates by liming when adding reagents containing aluminum", the authors studied the processes of mine water treatment from the mine "Kreminna" in the Donetsk region from sulphates when treated with lime, sodium aluminate or aluminum hydroxide. The authors proved that the efficiency of sulphate extraction depends on the type and consumption of reagents containing aluminum, as well as the method of pre-treatment of aluminum hydroxide [4].

In the article "Application of integrated forward and reverse osmosis for coal mine wastewater desalination" the authors evaluated the use of the integrated forward osmosis (FO) and reverse osmosis (RO) system with three different actual coal mine waters, containing various concentrations of sulphates and silica. The authors evaluated three different solutions for the extraction of forward osmosis: disodium hydrogen phosphate (DHSP), sodium hexametaphosphate
(SHMP), and sodium lignosulfonate (SLS). Two different ways of integrating forward and reverse osmosis have been identified [5]. As a result of the study, the authors came to the conclusion that the integrated physical and chemical treating system is able to restore more than $80 \%$ of the mine water, i. e. to treat it to the natural state of the surface waters.

Let us consider the example of biological technologies for treating mine waters. For example, in the article "Recent Developments for Remediating Acidic Mine Waters Using Sulfidogenic Bacteria" the authors discuss new approaches with using low sulfidogenic bioreactors to both remediate and selectively recover metal sulfides from the mine waters [6]. I. Nancucheo, J. Bitencourt, and P. Sahoo consider disadvantages of biological methods for treating mine waters, as well as the prospect of using of novel acidophilic and acid-tolerant sulfidogenic microorganisms when treating mine waters. Despite the existing problems, the authors see prospects in biological methods of mine water treatment, and also emphasize the need for further research in this area [6].

Thus, we have examined the main reasons due to which mine waters are considered to be dangerous for the water management complex of Ukraine, as well as the status and capabilities of physical, chemical and biological technologies of mine water treatment. The existing technologies, in general, make it possible to treat mine waters completely to the state of natural waters, and to minimize the risk of mine waters disturbing the basin balance of water management. However, the duration of mine water treatment, the high cost of treatment technologies, the imperfect legislative and regulatory framework in Ukraine, as well as the unfair attitude of mining companies to reducing the anthropogenic load on the ecosystem of regions, require special knowledge and continuous monitoring of mining enterprises and the process of mine water treatment. Special requirements are imposed on water management, which, according to the authors, should be formed in the competence in the structure of educational training programs in the specialty "Public Management and Administration" (for example [7]). New tasks, for which managers of water management complex of Ukraine should be prepared, will allow generating necessary competences. Corresponding knowledge and competences will allow excluding the possibility of the mine waters violating the basin balance of the development of the water management in Ukraine, as they achieved this, for example, in Great Britain. In Great Britain, in 1994 a nondepartmental public body 'The Coal Authority' was established [8], and in 1995 a non-departmental state 'The Environment Agency' (EA) was created [9]. Managers, whose functions include the protection and improvement of the environment in England, including the protection of groundwater and surface water, work in both organizations.

The need to form a special kind of competences in managers of water management complex also follows from the European Union directives in the field of water management. The guideline "Directives in the sphere of water resources management" contains documents that define the current and strategic goals of water management in the trends of economic, social, and environmental development of the European community [10].

Let us determine the tasks of the water management complex of Ukraine based on the results of the analysis of the characteristics of pollution of underground and natural surface waters by mine waters, as well as the imperfections of the existing technologies for the treatment of mine waters in Ukraine.

The main task facing the management of the water management complex of Ukraine remains unchanged: to ensure the basin balance of the development of water management, water protection and restoration of water resources based on the coherence of law and management actions [11].

Let us note that the current state administration of water management complex in Ukraine is regulated by four main laws of Ukraine: 
1. Water code of Ukraine [12].

2. The law of Ukraine "On the Basic principles (strategy) of the state environmental policy of Ukraine for the period up to 2030 " [13]

3. The Order of the Cabinet of Ministers of Ukraine "On Approval of the Concept of the National Target Program for the Development of Water Management for the Period until $2020 "$ " [2].

4. The law of Ukraine "On approval of the State target program of development of the water management complex and ecological improvement of the Dnipro river basin for the period up to 2021" [14]

Laws and regulations define the general functions of the water management complex in Ukraine. Let us select and consider the main ones:

1. Legal support of protection and rational use of water resources. Yu. Vystavna, M. Cherkashyna and M. R. van der Valk compared water laws of Georgia, Moldova, and Ukraine with the Water Framework Directive of the European Union [15]. The focus of their research was on the legal regulation of water quality control, water pollution, and water resources management. As a result of the analysis, the authors have come to the conclusion that the legislative base of Ukraine has the greatest number of contradictions and omissions, and that it corresponds to the European water legislation [16]. Accordingly, there is a question of further development of the legislative base of Ukraine and the need to bring it in line with the Water Framework Directive of the European Union [15].

2 . Development of programs for the protection and reproduction of water resources at the national, interstate and regional levels. For example, from January 1, 2013 the Law of Ukraine "On approval of the State target program of development of water management and ecological improvement of the Dnipro river basin for the period up to 2021 " came into force [14]. The law establishes the main directions of state policy in the field of water management to meet the needs of the population and sectors of the national economy in water resources, conservation and reproduction of water resources, the introduction of an integrated water resources management system on the basin principle, the restoration of the role of reclaimed land in the food and resource provision of the state, optimization of water consumption, prevention and elimination of the consequences of harmful effects of waters [14]. The current law is a clear example of the development of the state program of reproduction of the water management complex of Ukraine, as well as an example of public water management. However, there is a need to develop and adopt laws and other regulations that would affirm the need for programs for the protection and reproduction of water resources in other regions of Ukraine. For example, the regions of Donetsk and Lviv-Volyn coal basins, where mine reclamation requires the special control.

3 . Financial support of the programs of protection and reproduction of water resources of Ukraine in the conditions of market relations. In the collective monograph "Formation of the model of natural resources management in the market conditions of management", the authors proposed various models of natural resources management (including water management) through domestic sources of financing (public and private), as well as through the attraction of grants and foreign investments [17]. However, in Ukraine there is no strategy for financing the protection and reproduction of water resources, as well as mechanisms for monitoring financing and reports on financing. Analysis of the issues of the journal "Water Management of Ukraine" over the past two years has not helped the authors find any reports on financing of programs for the protection and reproduction of water resources of Ukraine, although the journal is published by the State Committee of Water Management of Ukraine and State Institute of Management and Economy of Water Resources (wherein it does not have an official website and electronic editions)
4. Meeting the needs of the population in high-quality drinking water. The following data is given on the UN official website: a) four out of every 10 people in the world are experiencing a shortage of quality drinking water; b) 340,000 children under five die of diarrheal diseases every year; c) $80 \%$ of wastewater is returned to the ecosystem without treatment; d) approximately $75 \%$ of all industrial water intakes are used for energy production [18]. As we can see the control over the quality of water and providing the population with quality drinking water is the primary task of water management in Ukraine. Underfinancing of programs and corruption in the Department, led to the fact that 36 thousand $\mathrm{km}$, or $35.5 \%$ of water lines from the total 101 thousand $\mathrm{km}$. (data for 2016), are in dilapidated or emergency condition [19].

5. Providing industries with the necessary number of water resources. In the collective monograph "Scientific principles of rational use of water resources of Ukraine on basin principle", the authors reveal the peculiarities of state water management. Ukraine has created nine basin water management departments (management of the rivers Dnipro, DniesterPrut, Western Buh, Siverskyi Donetsk, Danube, Desna, as well as basin management of the rivers Southern Buh, Tysa, Ros), which provide the required volume of water to all sectors of the economy of Ukraine [20]. However, the restructuring of water management in Ukraine in accordance with the Water Framework Directive of the European Union is still far from completion. Accordingly, the provision of industries with water resources is not always carried out in accordance with the European standards.

6. Implementation of measures to prevent water pollution, as well as the harmful effects of polluted water on the environment and human health. The EU Water Framework Directive, for compliance with which the legal basis of water management of Ukraine is oriented, states in the first paragraph, "Water is not a commercial product like any other but, rather, a heritage which must be protected, defended and treated as such" [16]. It is for this reason that the prevention of water pollution should begin with the education, with the formation of the established stereotype, worldview: water and its quality is a cultural heritage (for example, research [21]). Only just this attitude to water, environment and human health will increase the responsibility of mining managers and the quality of control by water managers of Ukraine, including for the treatment of mine waters.

Conclusions. The results of the research allow focusing the attention of public authorities, owners of mining enterprises, scientific and public organizations of the environmental orientation on the problem of the mine water management as a part of the global water safety system.

The analysis of the danger of mine water outflow into underground and natural surface waters, the analysis of modern methods of physical, chemical, and biological treatment of mine waters, as well as the general functions of water management, conducted by the authors, allow us to formulate the water management tasks aimed at reducing the impact of mine waters on the state of the water management complex of Ukraine. The tasks of the water management of Ukraine under the conditions of the existing danger of a violation of the basin balance of the development of water management in Ukraine by mine waters include the following:

1. Development of a strategy for the management of mine waters across the state and regions.

2. Development of organizational models for the functioning of the water management complex in the terms of mine water treatment. Each model should take into account the hydrogeological features of the region, the geochemical assessment of minerals and host rocks in the early stages of the mining enterprise to determine the activity of mine waters and the technogenic load of mining activities on biota and human health in the region, etc.

3. Improving of the economic mechanism for the protection of water resources of Ukraine from mine waters in need of 
treatment. The third task involves the ability to organize financing of mine water treatment programs at the expense of the state budget, the budget of mining enterprises, as well as grants and foreign investment.

4. Search for new effective technologies for treating mine waters and the ability to adapt them to the Ukrainian realities, namely, low-skilled labour, insufficient financing, lack of responsibility and self-control, etc.

5. Adaptation of legislative and regulatory documents of Ukraine to effective and constantly improving legislative and regulatory documents of highly developed countries of the world, in particular, to the EU Water Framework Directive.

6 . The ability to take responsibility and use the gained competencies and knowledge to prevent the disruption of the basin balance of the development of water management in Ukraine by mine waters.

According to the authors, the stated objectives clarify the role of water management in the environmental safety of the state, and they should be used in the structure of educational programs for training specialists in the specialty "Public Management and Administration".

\section{References.}

1. Younger, P., Banwart, S. A., \& Hedin, R. (2012). Mine Water: Hydrology, Pollution, Remediation. Springer.

2. Legislation of Ukraine (2009). On approval of the Concept of the National Target Program on Water Resources Management for the period 2020 Ordinance of the Cabinet of Ministers of Ukraine of September 3, 2009. N 1029-r. Retrieved from https://zakon.rada.gov.ua/laws/show/1029-2009-\%D1\%80.

3. Legislation of Ukraine (2009). On approval of the Regulation on the State Register of potentially dangerous objects (2013). Version of 17.04.2013. Retrieved from https://zakon.rada.gov.ua/ laws/show/1288-2002-\%D0\%BF.

4. Gomelya, N. D., Trus, I. M., \& Nosacheva, Yu. V. (2014). Water purification from sulfates with using aluminium-containing reagents. Khimiya i tekhnologiya vody, 36(2), 129137. Retrieved from http://dspace.nbuv.gov.ua/bitstream/ handle/123456789/130855/04-Gomelya.pdf?sequence $=1$.

5. Thiruvenkatachari, R., Francis, M., Cunnington, M., \& Su, Shi. (2016). Application of integrated forward and reverse osmosis for coal mine wastewater desalination. Separation and Purification Technology, 163, 181-188. https://doi. org/10.1016/j.seppur.2016.02.034.

6. Nancucheo, I., Bitencourt, J., Sahoo, P., Alves, J.O., Siqueira, J., \& Oliveira, G. (2017). Recent Developments for Remediating Acidic Mine Waters Using Sulfidogenic Bacteria. BioMed Research International, Article ID 7256582. https://doi.org/10.1155/2017/7256582.

7. Rudenko, S., Bazaluk, O., Tsvykh, V., \& Kalmuk, I. (2019). The Role of Philosophical Disciplines in Educational Strategies for Specialist Training in the Field of Public Administration. Naukovyi Visnyk Natsionalnoho Hirnychoho Universytetu, (3), 158-163. https://doi.org/10.29202/nvn$\mathrm{gu} / 2019-3 / 22$.

8. Coal Authority (2019). Retrieved from https://www.gov.uk/ government/organisations/the-coal-authority.

9. Environment Agency (2019). Retrieved from https://www. gov.uk/government/organisations/environment-agency.

10. Pinchuk, O. L., Herasimov, Ye.H., \& Kunytskyi, S. O. (2019). EU Water Directives: A Handbook. Rivne, Volyn coast. 11. Ievdokymov, V. O., \& Zhuk, V. M. (2015). State regulation of water economic complex through introduction of integrated approach to water resources management on the basis of the basin principle. Aktualni problemy derzhavnoho upravlinnia, 1(47), 139-145.

12. Legislation of Ukraine (2017). Water Code of Ukraine. Version of 12.18.2017. Retrieved from https://zakon.rada.gov.ua/ laws/show/213/95-\%D0\%B2\%D1\%80.

13. Legislation of Ukraine (2019). On the Basic Principles (Strategy) of the State Environmental Policy of Ukraine till 2030.
Adoption on February 28, 2019. Retrieved from https://zakon.rada.gov.ua/laws/show/2697-19.

14. Legislation of Ukraine (2012). On Adopting the National Target Program for Developing Water Management and Environmental Improvement of the Dnipro River Basin for the Period up to 2021. Adoption on May 24, 2012. Retrieved from https:// zakon.rada.gov.ua/laws/show/4836-17.

15. Vystavna, Y., Cherkashyna, M., \& van der Valk, M. (2018). Water laws of Georgia, Moldova and Ukraine: current problems and integration with EU legislation, Water International, 43(3), 424-435, https://doi.org/10.1080/02508060.2018.1447 $\underline{897}$.

16. EUR-Lex (2019). EU Water Framework Directive. Retrieved from https://eur-lex.europa.eu/legal-content/EN/ TXT/?uri=CELEX:32000L0060.

17. Hvesyka, M. A. (Ed.) (2013). Formation of natural resource management model in market conditions. Kyiv Institute of Environmental Economics and Sustainable Development of NAS of Ukraine, 2013.

18. United Nations (2019). Water. Retrieved from https:// www.un.org/en/sections/issues-depth/water/index.html.

19. Levkovska, L. V., \& Mandzyk, V. M. (2018). Formation of a model of integrated water management in the context of ensuring sustainable water use. Balanced nature management, (2), 46-53. Retrieved from http://natureus.org.ua/repec/archive/2 2018/7.pdf.

20. Stashuk, V.A. (Ed.) (2014). Scientific Basics of Rational Use Water of Ukraine by the Basin Principle. Kherson: Grin D.S., Retrieved from https://www.researchgate.net/profile/Vitalii Mokin/publication/281320828 Scientific Basics of Rational_Use_Water_of_Ukraine_by_the_Basin_Principle/ links/55e1d66b08aecb1a7cc826d9.pdf.

21. Bazaluk, O. (2019). The Revival of the Notion of Arete in Contemporary Philosophy. Schole, 13(1), 198-207. https:// doi.org/10.25205/1995-4328-2019-13-1-198-207.

\section{Вплив шахтних вод на стан водогосподарського комплексу України: завдання водогосподарського менеджменту}

\section{В. В. Шиачук, О. Л. Євмєшкіна, В. В. Кравченко}

Таврійський національний університет імені В. І. Вернадського, м. Київ, Україна, e-mail: gorbangalina1@gmail.com

Мета. Сформулювати завдання водогосподарського менеджменту України в умовах існуючої небезпеки порушення шахтними водами басейнової збалансованості розвитку водного господарства України.

Методика. Методологічною основою дослідження $є$ моделювання впливу шахтних вод на басейнову збалансованість водного господарства, аналіз, синтез і порівняння отриманих результатів.

Результати. Для досягнення поставленої мети автори розглянули: 1) причини, за якими шахтні води вважаються забруднюючим об'єктом, і, відповідно, небезпечним для водогосподарського комплексу Україну; 2) стан і можливості фізичних, хімічних і біологічних технологій очищення шахтних вод; 3) загальні функції водогосподарського менеджменту. Отримані результати дозволили сформулювати конкретні завдання водогосподарського менеджменту щодо недопущення порушення шахтними водами басейнової збалансованості розвитку водного господарства України.

Наукова новизна. Автори визначили завдання водогосподарського менеджменту України, грунтуючись на результатах аналізу особливостей забруднення шахтними водами підземних і природних поверхневих вод, а також недосконалості існуючих технологій очищення шахтних вод. 
Практична значимість. Дослідження розкриває роль водогосподарського менеджменту в екологічній безпеці держави. Результати можуть бути корисними в роботі державних органів управління, власників підприємств гірничодобувної галузі, наукових і громадських організацій екологічного спрямування із проблеми поводження iз шахтними водами як частини глобальної системи водної безпеки. Отримані результати можуть використовуватися у структурі освітніх програм підготовки фахівців за спеціальністю „Публічне управління та адміністрування“, а також розширювати кваліфікацію водогосподарського менеджменту всіх рівнів: від державного регулювання до управління в регіонах. Сформульовані завдання водогосподарського менеджменту забезпечать ефективне поводження із шахтними водами, а також басейнову збалансованість розвитку водного господарства України.

Ключові слова: шахтні води, водогосподарський комплекс, водогосподарський менеджмент, екологічна безпека, технології очищення

\section{Влияние шахтных вод на состояние водохозяйственного комплекса Украины: задачи водохозяйственного менеджмента}

\section{В. В. Шиачук, Е. Л. Евмешкина, В. В. Кравченко}

Таврический национальный университет имени В. И. Вернадского, г. Киев, Украина, e-mail: gorbangalina1@gmail. com

Цель. Сформулировать задачи водохозяйственного менеджмента Украины в условиях существующей опасности нарушения шахтными водами бассейновой сбалансированности развития водного хозяйства Украины.

Методика. Методологической основой исследования является моделирование влияния шахтных вод на бассейновую сбалансированность водного хозяйства, анализ, синтез и сравнение полученных результатов.

Результаты. Для достижения поставленной цели авторы рассмотрели: 1) причины, по которым шахтные воды считаются загрязняющим объектом, и, соответственно, опасным для водохозяйственного комплекса Украины; 2) состояние и возможности физических, химических и биологических технологий очистки шахтных вод; 3) общие функции водохозяйственного менеджмента. Полученные результаты позволили сформулировать конкретные задачи водохозяйственного менеджмента для недопущения нарушения шахтными водами бассейновой сбалансированности развития водного хозяйства Украины.

Научная новизна. Авторы определили задачи водохозяйственного менеджмента Украины, основываясь на результатах анализа особенностей загрязнения шахтными водами подземных и природных поверхностных вод, а также несовершенства существующих технологий очистки шахтных вод.

Практическая значимость. Исследование раскрывает роль водохозяйственного менеджмента в экологической безопасности государства. Результаты могут быть полезными в работе государственных органов управления, собственников горнодобывающих предприятий, научных и общественных организаций экологической направленности по проблеме обращения с шахтными водами как части глобальной системы водной безопасности. Полученные результаты могут использоваться в структуре образовательных программ подготовки специалистов по специальности „Публичное управление и администрирование“, а также расширят квалификацию водохозяйственного менеджмента всех уровней: от государственного регулирования до управления в регионах. Сформулированные задачи водохозяйственного менеджмента обеспечат эффективное обращение с шахтными водами и бассейновую сбалансированность развития водного хозяйства Украины.

Ключевые слова: шахтные воды, водохозяйственный комплекс, водохозяйственный менеджмент, экологическая безопасность, технологии очистки

Recommended for publication by Ya. F. Zhovnirchyk, Doctor of Sciences in Public Administration. The manuscript was submitted 02.02.19. 